\title{
Markery włóknienia w niewydolności serca
}

\author{
Fibrosis markers in heart failure
}

\author{
Bożena Karolko, Monika Przewłocka-Kosmala
}

Katedra i Klinika Kardiologii Uniwersytetu Medycznego im. Piastów Śląskich we Wrocławiu

\section{Streszczenie}

Niewydolność serca (HF) jest najczęstszą przyczyną zgonu z przyczyn sercowo-naczyniowych. Liczba zachorowań wzrasta, mimo postępu w dziedzinie farmakologii i medycyny interwencyjnej. Pociąga to za sobą ogromne nakłady finansowe na leczenie. Od lat prowadzone są badania nad wprowadzeniem do diagnostyki kardiologicznej nowych markerów biochemicznych wspomagających ustalenie rozpoznania, monitorowanie odpowiedzi na leczenie oraz prognozowanie ryzyka. Biomarkery są wykładnikiem patologicznych procesów zachodzących w niewydolnym mięśniu sercowym. Na szczególną uwagę zasługują biomarkery włóknienia - jednego z kluczowych patofizjologicznych mechanizmów wpływających na rozwój HF. Biomarkery włóknienia dają możliwość monitorowania postępu choroby i oceny stopnia niekorzystnych zmian. W niniejszej pracy przedstawiono zarówno dobrze już poznane, jak i nowe markery włóknienia oraz ich przydatność w diagnostyce HF.

Słowa kluczowe: markery biologiczne, niewydolność serca, włóknienie serca, macierz pozakomórkowa

Folia Cardiologica 2017; 12, 3: 245-253

\section{Wstęp}

Niewydolność serca (HF, heart failure) jest złożonym zespołem klinicznym, w którym serce wskutek upośledzenia jego struktury lub funkcji nie może pompować krwi w ilości niezbędnej do zapewnienia optymalnego funkcjonowania wszystkich narządów. Przyczyną HF są zaburzenia napełniania lub opróżniania komór rozwijające się w następstwie zaburzeń skurczu lub rozkurczu serca. Stąd wynika podział na skurczową i rozkurczową niewydolność serca, czyli na niewydolność serca z obniżoną frakcją wyrzutową lewej komory (HFrEF, heart failure with reduced ejection fraction) oraz niewydolność serca z zachowaną frakcją wyrzutową lewej komory (HFpEF, heart failure with preserved ejection fraction) [1, 2].

W krajach rozwiniętych choroba dotyka 2-3\% ludności. W Polsce choruje około miliona osób. Częstość występowania HF wzrasta z wiekiem pacjentów. Wśród osób powyżej 70. roku życia obserwuje się szczególnie wysoką zapadal- ność na HF, sięgającą 10-20\%. Niewydolność serca to jedyne schorzenie kardiologiczne, w którym liczba chorych wzrasta mimo ogromnego postępu w diagnostyce i terapii. Niewydolność serca jest schorzeniem o bardzo złym rokowaniu cechującym się wysoką śmiertelnością porównywalną (np. rak jelita) lub nawet większą od śmiertelności wśród osób z wieloma nowotworami (np. rak piersi czy rak gruczołu krokowego). Szacuje się, że połowa pacjentów z HF umiera w ciągu 5 lat od postawienia rozpoznania. Koszty ochrony zdrowia związane z HF są wysokie i średnio wynoszą 2,0-2,5\% całkowitych wydatków na cele zdrowotne w krajach uprzemysłowionych [3-5].

Wczesne rozpoznanie HF i wdrożenie odpowiedniego leczenia znacznie poprawia rokowanie i jakość życia chorych. Podstawowym narzędziem w diagnostyce HF u pacjentów zgłaszających objawy podmiotowe i przedmiotowe jest echokardiografia. Pozwala ona ocenić strukturę serca (masę, objętość, geometrię) i jego funkcję (m.in. frakcję wyrzutową lewej komory, kurczliwość ścian, czynność zastawek, ciśnienie

Adres do korespondencji: dr hab. n. med. Monika Przewłocka-Kosmala, Klinika Kardiologii Uniwersytetu Medycznego we Wrocławiu, ul. Borowska 213, 50-556 Wrocław, tel. 7173642 20, e-mail: monika.przewlocka-kosmala@umed.wroc.pl 
w tętnicy płucnej). Dostarcza podstawowych informacji pozwalających na różnicowanie skurczowej i rozkurczowej HF [6]. Ma jednak pewne ograniczenia, związane na przykład z trudnościami w obrazowaniu u osób starszych, szczególnie z chorobami współistniejącymi i po zabiegach kardiochirurgicznych, czy z subiektywnością oceny. Ponadto nie zawsze jest dostępna w warunkach szpitalnego oddziału ratunkowego.

Istotną rolę w diagnostyce HF mają markery biochemiczne. Jedynymi dotychczas w pełni zaaprobowanymi markerami w rozpoznaniu HF są peptydy natriuretyczne - peptyd natriuretyczny typu B (BNP, B-type natriuretic peptide) i N-końcowy fragment pro-BNP (NT-proBNP, Nterminal $B$-type natriuretic propeptide). Oznaczenia obydwu peptydów są w użyciu jako rutynowe testy laboratoryjne już od kilkunastu lat. W pewnych sytuacjach zastosowanie peptydów natriuretycznych jest jednak ograniczone ze względu na ich zmienność związaną z rytmem dobowym, objętością krwi krążącej, wiekiem, płcią, funkcją nerek [7]. W ostatnich latach prowadzono intensywne badania nad kilkunastoma nowymi biochemicznymi markerami mogacymi mieć zastosowanie we wczesnym rozpoznaniu HF, monitorowaniu leczenia oraz ocenie rokowania. Biomarkery odzwierciedlają wielorakość patofizjologicznych procesów towarzyszących HF. W zależności od procesu, w którym uczestniczą, można podzielić je na markery uszkodzenia miocytów (troponiny wysokiej czułości, sercowe białko wiążące kwasy tłuszczowe [H-FABP, heart-type fatty acid binding protein]), markery stanu zapalnego (interleukina 6, czynnik martwicy nowotworów $\alpha$ [TNF- $\alpha$, tumor necrosis factor $\alpha$ ], białko C-reaktywne [CRP, C-reactive protein],pentraksyna-3), markery neurohormonalnej aktywacji (endotelina 1, kopeptyna), markery włóknienia (gal, metaloproteinazy [MMP, matrix metalloproteinases]) oraz markery chorób współistniejących z HF (lipokalina związana z żelatynazą neutrofilów [NGAL, neutrophil gelatinase-associated lipocalin], cystatyna C). Ogromny technologiczny postęp pozwala na szybki pomiar stężenia tych substancji testami o bardzo wysokiej czułości [8].

Markery włóknienia odgrywają ważną rolę zarówno w ocenie czynnego procesu chorobowego w tkance serca, jak i w monitorowaniu procesów naprawczych zachodzących w mięśniu sercowym [9]. W niniejszej pracy przedstawiono dobrze już poznane, a także nowe markery włóknienia oraz ich przydatność w diagnostyce HF.

\section{Macierz pozakomórkowa miokardium}

Tkanka serca zbudowana jest z następujących elementów: kardiomiocytów, macierzy zewnątrzkomórkowej (ECM, extracelluar matrix), komórek macierzy zewnątrzkomórkowej, takich jak fibroblasty i makrofagi, oraz sieci naczyń krwionośnych. Kardiomiocyty stanowią 90\% masy mięśnia sercowego, ale tylko 30\% liczby wszystkich komórek ser- ca, pozostałe $70 \%$ komórek serca to głównie fibroblasty. Macierz pozakomórkowa jest tkanką łączną, która tworzy szkielet dla kardiomiocytów. Tkanka łączna otaczająca mięsień sercowy od zewnątrz nazywana jest namięsną (epimisium). Do wnętrza mięśnia wnikają pasma tkanki łącznej otaczające pęczki włókien mięśniowych nazywane omięsną (perimysium), natomiast pojedyncze włókienka mięśniowe otacza tkanka łączna nazywana śródmięsną (endomysium). Głównym składnikiem tkanki łącznej jest kolagen syntetyzowany przez fibroblasty. W mięśniu sercowym występują głównie dwa typy kolagenu - I i III. Izoforma kolagenu typu I tworzy grube włókna zbudowane z pęczków prążkowanych fibryli odpornych na rozerwanie. Prążkowanie fibryli wynika z uporządkowanego układu cząsteczek kolagenu w fibryli. Poszczególne fibryle łączą się ze sobą, tworząc włókno przez sieć kowalencyjnych wiązań poprzecznych. Kolagen typu III tworzy sieć cienkich włókien o dużych, elastycznych oczkach podatnych na rozciąganie. Kolagen typu I i kolagen typu III pozostaja w stanie równowagi i decydują o mechanicznej skuteczności skurczu i rozkurczu serca. W ECM ciągle zachodzi synteza nowych włókien kolagenu oraz jego degradacja. Degradacja następuje przy udziale metaloproteinaz, których aktywność jest regulowana przez ich tkankowe inhibitory. Oba typy białek wydzielane są przez fibroblasty. Metabolizm kolagenu regulują również takie czynniki jak angiotensyna II, transformujący czynnik wzrostu $\beta_{1}$, aldosteron oraz TNF- $\alpha[10]$.

\section{Włóknienie miokardium}

Patologiczne procesy, takie jak obciążenie mechaniczne, zapalenie, niedokrwienie, stres oksydacyjny czy nadmierna aktywacja neurohormonalna, prowadzą do zaburzenia homeostazy przestrzeni pozakomórkowej i w konsekwencji do przewagi syntezy kolagenu nad jego degradacją, powodując włóknienie mięśnia sercowego. Proces włóknienia upośledza właściwości mechaniczne miocytów, wpływa na sztywność tętnic, sprzyja zaburzeniom skurczu i rozkurczu, wywołuje dysfunkcję lewej komory, zakłóca elektrofizjologię komórek serca oraz indukuje zaburzenia rytmu. W konsekwencji prowadzi to do niekorzystnej przebudowy mięśnia sercowego i rozwoju HF.

Wyróżnia się dwa podstawowe typy włóknienia występujące w tkance serca:

- włóknienie zastępcze (naprawcze) polegające na wypełnianiu przestrzeni po martwych miocytach tkanką łączną; ten typ włóknienia jest ograniczony do jednego obszaru tkanki (charakterystycznym przykładem włóknienia zastępczego jest tworzenie blizny po zawale serca);

- włóknienie reaktywne (rozsiane), które obejmuje przestrzeń okołonaczyniową oraz tkankę śródmiąższową bez obserwowanej utraty miocytów, ten typ włóknienia częściej występuje w populacji osób starszych oraz 
dominuje u osób z HF spowodowaną nadciśnieniem tętniczym, kardiomiopatią przerostową oraz zwężeniem zastawki aortalnej [11].

Włóknienie miokardium występuje zarówno w skurczowej, jak i rozkurczowej HF. W niewydolności skurczowej następuje zwiększona degradacja endo- i perimysium przez metaloproteinazy, jednak całkowita ilość kolagenu wzrasta poprzez nasilone odkładanie kolagenu w epimysium, w pobliżu naczyń oraz w przestrzeniach po martwych miocytach. Skutkiem tych niekorzystnych zmian jest rozsuwanie się kardiomiocytów prowadzące do rozstrzeni. Procesy włóknienia w rozkurczowej HF charakteryzuje zwiększona synteza kolagenu w endo- i perimysium $[12,13]$.

Niezależnie od różnych patofizjologicznych mechanizmów prowadzących do rozwoju włóknienia, na poziomie komórkowym proces przebiega podobnie, z aktywacją tych samych szlaków sygnalizacyjnych i udziałem podobnych czynników profibrotycznych. Aktywacja fibroblastów i ich transformacja do miofibroblastów odgrywa kluczową rolę w rozwoju włóknienia. Miofibroblasty regulują obrót kolagenu i są głównymi komórkami odpowiedzialnymi za naruszenie równowagi między syntezą i degradacją kolagenu oraz nadmierną produkcję zwłaszcza fibrylarnego kolagenu typu I w stosunku do kolagenu typu III. Nadmiernemu odkładaniu kolagenu towarzyszą zmiany stężenia oraz składu innych białek macierzy pozakomórkowej, wpływając na ilość tkanki łącznej oraz jej właściwości. Oprócz metaloproteinaz i ich inhibitorów do białek tych zaliczyć można między innymi fibronektynę, trombospondyny, tenascynę $\mathrm{C}$, osteopontynę, białko osteonektyna (SPARC, secreted protein acidic and rich in cysteins), galektynę 3 (gal-3), oksydazę lizylową czy czynnik wzrostu tkanki łącznej (CTGF, connective tissue growth factor). Transformacja fibrobastów do miofibroblastów może być indukowana przez wiele czynników, takich jak obciążenie mechaniczne, działanie cytokin, hormonów, reaktywnych form tlenu czy czynników wzrostu [14, 15]. Do najważniejszych, najsilniejszych i najlepiej zbadanych należy transformujący czynnik wzrostu ß (TGF-ß, tissue growth factor $ß)$. Odgrywa on kluczową rolę w proliferacji fibroblastów transformacji do miofibroblastów. Ponadto TGF-ß乃 pośredniczy w rozpoznaniu i przenoszeniu sygnałów do jądra komórkowego skutkujących zmianą ekspresji białek macierzy zewnątrzkomórkowej. TGF-ß乃 hamuje degradację macierzy pozakomórkowej poprzez hamowanie aktywności metaloproteinaz i stymulację syntezy ich tkankowych inhibitorów. Wiele czynników stymuluje aktywację transformującego czynnika wzrostu. Należą do nich między innymi angiotensyna II, białko macierzy trombospondyna 1, proteazy, takie jak plazmina, a nawet metaloproteinazy 2 i 9 [16].

W procesie niekorzystnej przebudowy mięśnia sercowego uczestniczą również pośrednio inne komórki, takie jak makrofagi, komórki tuczne, limfocyty, komórki naczyń oraz miocyty. Wpływają na proces włóknienia przez produkcję różnych substancji będących mediatorami włóknienia [14].

\section{Markery ECM}

Jednym ze sposobów nieinwazyjnej oceny postępu włóknienia w przebiegu HF jest pomiar stężenia białek zaangażowanych w regulację metabolizmu kolagenu. Od wielu lat uwagę naukowców przyciągają metaloproteinazy ECM. stanowią one grupę endopeptydaz, którym do aktywności enzymatycznej niezbędne są jony cynku i wapnia w centrum katalitycznym. Enzymy można podzielić na następujące grupy: kolagenazy (MMP-1, MMP-8), żelatynazy (MMP-2, MMP-9), stromielizyny (MMP-3, MMP-10) i elastazy (MMP-7, MMP-12). Metaloproteinazy odpowiadają za degradację kolagenu i innych białek macierzy pozakomórkowej, podczas gdy ich naturalne tkankowe inhibitory hamują ten proces. Do tej pory zidentyfikowano cztery tkankowe inhibitory MMP: TIMP-1 (tissue inhibitors of metalloproteinases), TIMP-2, TIMP-3 oraz TIMP-4. Aktywność oraz stężenie MMP mogą regulować również cytokiny (interleukina 1, TNF- $\alpha$ ) lub zmiana pH środowiska [17].

W przebiegu HF aktywność MMP oraz ich tkankowych inhibitorów ulega zmianie. Uważa się, że w HFrEF zwiększa się aktywność tych enzymów wskutek zmniejszenia aktywności ich inhibitorów (przewaga degradacji kolagenu nad syntezą), natomiast w HFpEF mamy do czynienia z sytuacją odwrotną (przewaga syntezy kolagenu nad degradacją). Ma to odzwierciedlenie w wynikach badania Framingham, które wykazało dodatnią korelację między stężeniem osoczowej MMP-9 a powiększonym wymiarem końcowo-rozkurczowym lewej komory oraz zmniejszoną grubością jej ściany [18]. W innych badaniach udowodniono, że HFpEF może towarzyszyć wzrost aktywności wybranych MMP. Dotyczyło to w szczególności MMP-2, MMP-8 oraz MMP-9. Sugeruje się, że MMP-2 ma większą skuteczność w rozpoznaniu HFpEF, lepszą nawet od BNP [19]. Z kolei w badaniu służącym ocenie wartości prognostycznej TIMP-1 u pacjentów z przewlekłą HF wskazano na jego istotną wartość jako wskaźnika śmiertelności w tej grupie chorych [20].

Bardzo interesujące wyniki uzyskano w badaniach stężeń panelu markerów obrotu kolagenu oraz aktywności MMP i ich inhibitorów w wykrywaniu przerostu lewej komory. Do analiz włączono 241 zdrowych osób, 144 osoby z przerostem lewej komory bez stwierdzonej HF oraz 61 osób z przerostem lewej komory i potwierdzoną HFpEF. Podwyższone stężenia następujących czynników: MMP-7, MMP-9, TIMP-1 oraz markera aktywnego obrotu kolagenu odpowiadającego za jego synteze - N-końcowy propeptyd prokolagenu typu III (PIIINP, N-terminal propeptide of procollagen type III) korelowały z obecnością przerostu. Podwyższone stężenia MMP-2, MMP-8, TIMP-4 oraz PIIINP okazały się skuteczniejsze w wykrywaniu przerostu z HFpEF [21].

Obecne we krwi obwodowej markery obrotu kolagenu: C-końcowy propeptyd prokolagenu typu I (PICP, C-terminal 
pro-peptide of procollagen type I), PIIINP oraz C-końcowy telopeptyd kolagenu typu I (CITP, C-terminal telopeptide of collagen type I) od lat są obiektem zainteresowania badaczy zajmujących się HF. Udowodniono, że szczególnie PIIINP ma wartość prognostyczną w przewidywaniu ponownej hospitalizacji oraz śmiertelności z powodu zastoinowej HF [22]. Wysokie osoczowe stężenie PIIINP wiąże się również ze zwiększonym ryzykiem zgonu oraz hospitalizacji w grupie chorych z przewlekłą HF poddawanych standardowej terapii farmakologicznej [23].

Markery obrotu kolagenu mogą być użytecznymi wskaźnikami włóknienia, zwłaszcza u pacjentów ze zdiagnozowaną HFpEF. Stwierdzono, że CITP jest silnym czynnikiem prognostycznym zgonu i hospitalizacji w tej grupie chorych. Wysokie stężenie markerów obrotu kolagenu wiąże się również z pogorszeniem funkcji rozkurczowej lewej komory w HFpEF [24].

Stężenia zarówno PIIINP, jak i PICP korelują z parametrami włóknienia ocenianymi w materiale z biopsji serca pacjentów z rozwiniętą HF spowodowaną nadciśnieniem czy kardiomiopatią rozstrzeniową. Wykazano silną zależność między wysokim stężeniem PICP w surowicy pacjentów z HF i nadciśnieniem tętniczym a objętością frakcji kolagenu typu I (CIVF, collagen type I volume fraction) - wskaźnikiem mierzonym w próbkach tkanki serca specjalną automatyczną techniką analizy z wykorzystaniem monoklonalnych przeciwciał przeciwko kolagenowi typu I. Podobnie stężenie PIIINP u pacjentów z kardiomiopatią rozstrzeniową w znacznym stopniu koreluje z objętością frakcji kolagenu typu III (CIIIVF, collagen type III volume fraction) ocenianym w próbkach z biopsji z zastosowaniem tej samej techniki morfometrycznej i użyciem monoklonalnych przeciwciał przeciw kolagenowi typu III [25].

W licznych badaniach na modelach zwierzęcych udowodniono, że włóknienie miokardium wiąże się nie tylko z nadmierną produkcją kolagenu, ale również ze wzrostem usieciowania poprzecznego fibryli kolagenu wewnątrz włókien. Poszczególne fibryle łączą się ze sobą poprzez sieć kowalencyjnych wiązań. W procesie tym pośredniczy enzym oksydaza lizylowa [26]. Wzmożona ekspresja enzymu wiąże się ze wzrostem usieciowania kolagenu i obniżoną funkcją rozkurczową w modelu doświadczalnym myszy z indukowanym zespołem metabolicznym [27]. Wyniki badania u pacjentów z HF wykazały podobną korelacje. Wzrost liczby wiązań poprzecznych kolagenu oraz nadekspresja oksydazy lizylowej powodowały wzrost sztywności oraz ciśnienia napełniania lewej komory u tych pacjentów [28].

Ostatnio wysunięto hipotezę, że wzmożone usieciowanie poprzeczne włókien kolagenu wiąże się z ryzykiem hospitalizacji i zgonu z przyczyn sercowych u pacjentów z HF i nadciśnieniem tętniczym. Wzrost usieciowania poprzecznego powoduje tworzenie włókien kolagenu o zwiększonej grubości i sztywności, które stają się oporne na degrada- cję przez MMP-1. Skutkuje to jednocześnie obniżeniem stężenia CITP. W tej populacji chorych stosunek CITP/ /MMP-1 pozwala na identyfikację chorych z podwyższonym usieciowaniem poprzecznym włókien kolagenu i wysokim ryzykiem hospitalizacji [29].

\section{Galektyna 3}

Ostatnie dwie dekady to poszukiwanie nowych białek związanych z procesami włóknienia serca, które można by wykorzystać jako biomarkery w diagnostyce i terapii HF $[9,30]$.

Największe nadzieje badaczy wiążą się z gal-3. Ludzka gal-3 jest przedstawicielem rodziny białek lektynowych wiążących beta-galaktozydy (głównie ligandy zawierające laktozę i N-acetylolaktozoaminę), pełniących różnorakie funkcje w organizmie. Ma swój udział w wielu istotnych procesach zachodzących w komórkach, między innymi w ich wzroście i różnicowaniu, sygnalizacji komórkowej, apoptozie i adhezji międzykomórkowej [31]. Jedną z istotnych funkcji tego białka jest wpływ na procesy włóknienia. Procesy, takie jak zapalenie czy niedokrwienie, uszkadzają miokardium i prowadzą do aktywacji komórek układu odpornościowego, między innymi makrofagów. Aktywowane makrofagi wytwarzają gal-3, która powoduje włóknienie serca poprzez aktywację i nasilenie proliferacji sercowych fibroblastów. Aktywowane fibroblasty produkują kolagen - zwłaszcza typu I, który jest odpowiedzialny za sztywność mięśnia sercowego, prowadząc do zaburzeń skurczu i rozkurczu serca. Udział gal-3 w patologicznej przebudowie miokardium powoduje, że białko to jest mediatorem procesów włóknienia tkanki serca prowadzących do progresji HF. Gal-3 nie tylko odzwierciedla niekorzystne zmiany zachodzące w sercu, ale również bierze czynny udział w patologicznej przebudowie mięśnia sercowego [32-34].

W ciągu ostatnich lat oceniano użyteczność gal-3 jako biomarkera w kilkunastu randomizowanych badaniach klinicznych. Głównym celem badań klinicznych było wykazanie, czy pomiar stężenia gal-3 w surowicy lub osoczu pomaga:

- ustalić rozpoznanie HF;

- przewidywać krótkoterminową i długoterminową chorobowość oraz śmiertelność;

- monitorować odpowiedź na stosowane leczenie. Wyniki przeprowadzonych badań pozwoliły na sformułowanie kilku wniosków:

- stężenie gal-3 w populacji ogólnej koreluje z wieloma czynnikami ryzyka chorób układu sercowo-naczyniowego: podwyższonymi ciśnieniem tętniczym i stężeniem lipidów w surowicy, zwiększonym wskaźnikiem masy ciała (BMI, body mass index), upośledzoną funkcją nerek. Istnieje zależność między wiekiem a stężeniem gal-3. Wyższe wartości gal-3 obserwowano u kobiet (badanie PREVEND) [35]; 
- wyższe stężenie gal-3 stwierdza się w grupie pacjentów, u których podłożem ostrej duszności jest HF, koreluje ono z niektórymi echokardiograficznymi parametrami dysfunkcji lewej komory (wyższe ciśnienie napełniania, zaburzenia rozkurczu) oraz ze stężeniem NT-proBNP. Gal-3 ma nieco mniejszą wartość diagnostyczną dla rozpoznania choroby niż NT-proBNP, ale zdecydowanie większą wartość w przewidywaniu zgonu lub powtórnej hospitalizacji (badanie PRIDE) [32];

- w grupie pacjentów z zaawansowaną postacią HF podwyższone wyjściowe stężenie gal-3 wiąże się z większą śmiertelnością (badanie DEAL-HF) [34];

- u pacjentów leczonych z powodu ostrych zespołów wieńcowych wyższe wyjściowe stężenie gal-3 łączy się z większym ryzykiem rozwoju HF w ciągu 2 lat od momentu wystąpienia zawału (badanie PROVE-IT) [35];

- nie ma istotnych różnic między stężeniem gal-3 u pacjentów z zachowaną frakcją wyrzutową lewej komory w porównaniu z pacjentami z obniżoną frakcją wyrzutową, ale podwyższone stężenie białka jest lepszym czynnikiem rokownicznym zgonu lub ponownej hospitalizacji w HFpEF; stężenie gal-3 wykazuje się mniejszą zmiennością w czasie w porównaniu z peptydami natriuretycznymi, stąd seryjne oznaczenia gal-3 nie mają większego znaczenia rokowniczego niż oznaczenie wyjściowe [36];

- stwierdzono dodatnią korelację między stężeniem gal-3 a markerami stanu zapalnego (CRP, interleukiną 6) oraz markerami obrotu macierzy pozakomórkowej (MMP-2, TIMP-1) [37];

- badanie CORONA oraz Val-HeFT, oceniające skuteczność leczenia farmakologicznego pacjentów z HF w odniesieniu do poziomu gal-3, wykazało, że tylko pacjenci z niskimi stężeniami białka odnoszą korzyści z zastosowanego leczenia farmakologicznego [38].

Rezultaty uzyskane w wyżej wymienionych badaniach klinicznych były bardzo obiecujące; dawały podstawy do uznania gal-3 jako ważnego biomarkera włóknienia przydatnego w ocenie rokowania chorych z rozpoznaniem HF. Wyniki ostatnich badań klinicznych podważaja jednak twierdzenie, że stężenie gal-3 odzwierciedla stopień zwłóknienia miokardium w HF. Jednym z czynników mających wpływ na niekorzystne skutki HF jest funkcja nerek. Upośledzenie czynności nerek towarzyszące HF może w zasadniczy sposób wpływać na stężenie gal-3 we krwi obwodowej [39]. Podwyższone stężenie gal-3 w osoczu może wskazywać bardziej na progresję włóknienia nerek niż serca.

W badaniu klinicznym RELAX, do którego włączono 208 pacjentów z zaawansowaną HFpEF, sprawdzano, czy podwyższony poziom gal-3 wiąże się z niekorzystną przebudową i zaburzeniami funkcji serca. W badaniu wykazano niewielką korelację między podwyższonymi stężeniami gal-3 a stopniem koncentrycznej przebudowy serca. Nie stwierdzono natomiast związku między pozio- mem gal-3 a przerostem lewej komory, czy dysfunkcją skurczową lub rozkurczową. W wieloczynnikowej analizie statystycznej, po włączeniu takich parametrów, jak wiek, płeć oraz stężenie cystatyny $\mathrm{C}$, zanika związek między stopniem koncentrycznej przebudowy miokardium a stężeniem gal-3. Podobnie, korelacja między stężeniem gal-3 a maksymalną objętością tlenu mierzoną w sześciominutowym teście wysiłkowym traci statystyczną istotność po uwzględnieniu wieku, płci oraz stężenia cystatyny $\mathrm{C}$. Wysokie stężenie gal-3 nie wyklucza jej związku z włóknieniem serca, wskazuje raczej na sercowo-nerkowe podłoże włóknienia [40].

\section{MikroRNA}

Duże zainteresowanie badaczy budzą ostatnio cząsteczki mikroRNA (miRNA) ze względu na ich rolę w rozwoju różnych chorób, w tym chorób serca i naczyń.

MiRNA należą do grupy jednoniciowych, niekodujących sekwencji RNA składających się z 18-23 nukleotydów. Działanie miRNA polega na regulacji genów poprzez wiązanie się z komplementarnymi sekwencjami w mRNA i hamowaniu translacji docelowego mRNA. Efektem tego działania jest najczęściej zahamowanie syntezy danego białka. Dany typ miRNA może zmieniać zarówno ekspresję wielu genów, jak i na jeden gen może działać wiele typów miRNA. Cząsteczki miRNA biorą udział w regulacji wielu procesów zachodzących w komórkach: przekazywania sygnałów między komórkami, proliferacji, różnicowania czy apoptozy [41].

Do tej pory w bazie bioinformatycznej miRBase (www.mirbase.org) u człowieka zarejestrowano ponad 2500 typów miRNA. Cząsteczki miRNA występują zarówno wewnątrz komórek, jak i w przestrzeni międzykomórkowej oraz w płynach ustrojowych (surowicy, osoczu i moczu) [42]. Prowadzone są intensywne badania nad rolą miRNA w patogenezie chorób sercowo-naczyniowych [43]. W badaniach na modelach zwierzęcych udowodniono, że miRNA wpływają również na procesy włóknienia i patologicznego przerostu serca poprzez modulowanie procesów komórkowych zachodzących w kardiomiocytach i macierzy pozakomórkowej. Spośród miRNA, mających wpływ na włóknienie, należy wymienić cząsteczki miR-24, miR-133a, miR-30, miR-21 i miR-29. Szczególną rolę w procesie włóknienia przypisuje się dwóm typom cząsteczek miRNA: miR-21 oraz rodzinie miR-29 [44].

W eksperymencie polegającym na indukowaniu zawału w mysich sercach obserwowano wzrost ekspresji miR-21 w fibroblastach tkanki objętej zawałem. Udowodniono, że miR-21 hamuje ekspresje genu PTEN (phosphatase and tensin homolog) i wzrost aktywności MMP-2 w fibroblastach [45].

Wyniki kolejnych badań na modelach doświadczalnych wykazały wzrost miR-21 w fibroblastach transgenicznych 
myszy z HF. MiR-21 moduluje ekspresję genu kodujacego białko Sprouty 2 - antagonistę czynnika wzrostu fibroblastów. Zahamowanie aktywności Sprouty 2 przez miR-21 prowadzi do wzrostu syntezy czynnika wzrostu fibroblastów i wydłużenia czasu przeżycia tych komórek, które kontrolują proces włóknienia. W eksperymentach wykazano też udział miR-21 w regulacji genu białka Sprouty 1. Nadmierna ekspresja miR-21 hamuje apoptoze fibroblastów, powoduje wzrost ich aktywności nasilając włóknienie. Eksperymenty na fibroblastach pokazały, że nadekspresja miR-21 nasila syntezę kolagenu w wyniku supresji anatagonisty transformującego czynnika wzrostu $\beta$ - TGF-ßRIII, z kolei wzrost ekspresji TGF-ßRRIII hamuje miR-21 i obniża produkcję kolagenu [46]. Wyniki badań na modelach zwierzęcych znalazły potwierdzenie w badaniach ludzkich tkanek pochodzących z mięśnia sercowego oraz w płynach ustrojowych (osoczu, surowicy). W badaniach oceniających obecność tkankowego i osoczowego miR-21 u pacjentów ze zwężeniem zastawki aortalnej stwierdzono znacznie wyższe stężenie zarówno osoczowego, jak i tkankowego miR-21 w grupie chorych w porównaniu ze zdrowymi ochotnikami. Nie stwierdzono obecności miR-21 w kardiomiocytach, wykazano natomiast korelację między stężeniem miR-21w osoczu i tkance śródmiąższowej [47].

Innym typem miRNA zaangażowanym $\mathrm{w}$ regulacje procesu włóknienia jest rodzina miR-29 (miR-29a, b, c). Wykazano udział cząsteczki miR-29 w modyfikacji ekspresji genów odpowiedzialnych za syntezę kolagenu typu I i III, elastyny oraz fibryliny 1 . W badaniach in vivo na zdrowych szczurzych sercach oraz eksperymentach in vitro na kulturach tkankowych fibroblastów udowodniono, że hamowanie ekspresji miR-29 wzmaga syntezę kolagenu, potwierdzając tym samym bezpośredni udział cząsteczki w przebudowie macierzy pozakomórkowej. Ponadto, ekspresja miR-29 jest powiązana ze znanym regulatorem włóknienia - TGF- $\beta$ [48]. Podobnie jak w przypadku miR-21 głównym źródłem miR-29 są fibroblasty, ale obecność cząsteczek miR-29 wykryto również w krwiobiegu.

U pacjentów z kardiomiopatią przerostową przebadano 21 różnych miRNA obecnych w krwiobiegu. Stężenie 12 z nich było znacząco wyższe w grupie chorych w porównaniu z osobami zdrowymi, a analiza krzywych ROC wykazała, że stężenie ośmiu spośród 12 pozwala odróżnić osoby chore od zdrowych. Jedynie stężenie miR-29a korelowało natomiast dodatnio zarówno z przerostem, jak i włóknieniem potwierdzonym w badaniu rezonansem magnetycznym [49].

To właśnie cząsteczki miRNA obecne w płynach ustrojowych budzą największe nadzieje badaczy jako potencjalne biomarkery, głównie ze względu na łatwe pozyskiwanie materiału oraz ich dość dużą stabilność.
Prowadzone są badania nad znalezieniem pozakomórkowych miRNA charakterystycznych dla HF. Z grupy 186 „krążących” miRNA poddanej analizie wyselekcjonowało grupe czterech cząsteczek charakterystycznych dla HF: miR-423-5p, miR-320a, miR-22 i miR-92b. Wykazano korelację między stężeniem wybranych miRNA a takimi znanymi parametrami HF, jak stężenie BNP, przerost lewej komory czy powiększenie lewego przedsionka. Inne badanie pozwoliło na odkrycie powiązania między stężeniem pozakomórkowego miR-499 i miR-122 a ostrą HF [50].

Analizy nad przydatnością cząsteczek miRNA w diagnostyce chorób 42ad4 sercowo-naczyniowego są bardzo obiecujące, wymagają jednak dalszych szeroko zakrojonych badań klinicznych.

\section{Podsumowanie}

Ogromna liczba badań i publikacji wskazuje na dojmującą potrzebę znalezienia nowych markerów przydatnych w diagnostyce HF. Biomarkery włóknienia stanowią ważną grupę wskaźników pozwalających na wczesne wykrycie patologii. Ocena zmian ich stężenia we krwi pozwala na monitorowanie przebiegu choroby, śledzenie reakcji na leczenie i prognozowanie ryzyka. Badania stężenia osoczowych biomarkerów włóknienia są prostymi, nieinwazyjnymi i łatwo dostępnymi metodami pomiaru postępu tego procesu. Aby można uznać daną substancję za użyteczny biomarker włóknienia i wprowadzić do codziennej klinicznej praktyki, konieczne jest jednak udowodnienie związku jej stężenia z parametrami włóknienia zbadanymi w biopsji czy drogą magnetycznego rezonansu jądrowego. Należy potwierdzić, czy stężenie danej substancji koreluje zarówno z objętością frakcji sercowego kolagenu (CVF, collagen volume fraction) mierzoną w biopsji, czy tak zwaną objętością pozakomórkową (ECV, extracellular volume) badaną w magnetycznym rezonansie jądrowym. Warto zaznaczyć, że gal-3 jest już markerem wprowadzonym do diagnostyki laboratoryjnej HF. Amerykańska Agencja ds. Żywności i Leków zatwierdziła testy diagnostyczne do oznaczeń gal-3 jako pomoc w ocenie rokowania u chorych z przewlekłą HF. Od 2013 roku automatyczna wersja testu jest dostępna w Europie. Należy jednak pamiętać, aby przy interpretacji wyników oznaczeń stężenia gal-3 we krwi uwzględnić ocenę funkcji nerek. Obiecujące są dotychczasowe wyniki badań nad rolą cząsteczek miRNA w patofizjologii HF, wymagają jednak jeszcze oceny na dużych grupach osób chorych i zdrowych dla potwierdzenia ich przydatności w praktyce klinicznej.

\section{Konflikt interesów}

Autorki nie zgłaszają konfliktu interesów. 


\section{Abstract}

Cardiovascular diseases, especially heart failure (HF) are the major cause of death worldwide. HF is a leading health problem with an increasingly incidence and prevalence of the disease, despite advances in medical therapy and interventional cardiology. The treatment of heart failure represents a significant financial burden for healthcare system.

For many years there has been an intense research conducted to find the biological markers that aid in diagnosis, treatment and prognosis, and assessing the effectiveness of therapeutic intervention. They may provide valuable information for risk stratification. Biomarkers reflect different pathogenic processes in failed heart and correlate with changes in myocardial structure or function. Fibrosis plays an important role in cardiac remodelling that occurs in heart failure. Plasma biomarkers of fibrosis can be evaluated as prognostic indicators of myocardial accumulation of fibrous tissue. They correlated with the extent of cardiac fibrosis. Circulating biomarkers may be a useful tools to monitor the disease severity and therapeutic response. In our review we aim to analyze the role of well-known and novel biomarkers in the development of heart failure and their potential clinical utility in diagnostics of HF.

Key words: biological markers, heart failure, myocardial fibrosis, extracellular matrix

Folia Cardiologica 2017; 12, 3: 245-253

\section{Piśmiennictwo}

1. Colucci WS, Braunwald E. Pathophysiology of heart hailure. In: Braunwald WS, Zippes DP, Libby P. ed. Heart disease. Ed. 6. WB Saunders Company, Philadelphia 2001: 503-533.

2. Dickstein K, Cohen-Solal A, Filippatos G, et al. ESC Committee for Practice Guidelines (CPG), ESC Committee for Practice Guidelines (CPG). ESC Guidelines for the diagnosis and treatment of acute and chronic heart failure 2008: the Task Force for the Diagnosis and Treatment of Acute and Chronic Heart Failure 2008 of the European Society of Cardiology. Developed in collaboration with the Heart Failure Association of the ESC (HFA) and endorsed by the European Society of Intensive Care Medicine (ESICM). Eur Heart J. 2008; 29(19): 2388-2442, doi: 10.1093/eurheartj/ehn309, indexed in Pubmed: 18799522.

3. Karasek D, Kubica A, Sinkiewicz W, et al. Epidemiologia niewydolności serca - problem zdrowotny i społeczny starzejących się społeczeństw Polski i Europy. Folia Cardiol Excerpta. 2008; 5: 242-248.

4. Gierczyński J, Gryglewicz J, Karczewicz E, Zalewska H. ed. Niewydolność serca - analiza kosztów ekonomicznych i społecznych. Uczelnia Łazarskiego, Warszawa 2013.

5. Swedberg K, Cleland J, Dargie H, et al. Task Force for the Diagnosis and Treatment of Chronic Heart Failure of the European Society of Cardiology. Guidelines for the diagnosis and treatment of chronic heart failure: executive summary (update 2005): The Task Force for the Diagnosis and Treatment of Chronic Heart Failure of the European Society of Cardiology. Eur Heart J. 2005; 26(11): 1115-1140, doi: 10.1093/eurheartj/ehi204, indexed in Pubmed: 15901669.

6. Yancy C, Jessup M, Bozkurt B, et al. Writing Committee Members, American College of Cardiology Foundation, American Heart Association Task Force on Practice Guidelines. 2013 ACCF/AHA guideline for the management of heart failure: executive summary: a report of the American College of Cardiology Foundation/American Heart Association Task Force on practice guidelines. Circulation . 2013; 128(16): e240-e327, doi: 10.1161/CIR.0b013e31829e8776, indexed in Pubmed: 23741058.

7. Thygesen K, Mair J, Mueller C, et al. Study Group on Biomarkers in Cardiology of the ESC Working Group on Acute Cardiac Care. Recom- mendations for the use of natriuretic peptides in acute cardiac care: a position statement from the Study Group on Biomarkers in Cardiology of the ESC Working Group on Acute Cardiac Care. Eur Heart J. 2012; 33(16): 2001-2006, doi: 10.1093/eurheartj/ehq509, indexed in Pubmed: 21292681.

8. Iqbal N, Wentworth B, Choudhary R, et al. Cardiac biomarkers: new tools for heart failure management. Cardiovasc Diagn Ther. 2012; 2(2): 147-164, doi: 10.3978/j.issn.2223-3652.2012.06.03, indexed in Pubmed: 24282708.

9. Passino C, Barison A, Vergaro G, et al. Markers of fibrosis, inflammation, and remodeling pathways in heart failure. Clin Chim Acta. 2015; 443: 29-38, doi: 10.1016/j.cca.2014.09.006, indexed in Pubmed: 25218738.

10. Beręsewicz A, Duda M, Klemenska E. Patofizjologia niewydolności serca. Centrum Medyczne Kształcenia Podyplomowego, Warszawa 2010: 40-43.

11. Weber KT, Pick R, Jalil JE, et al. Patterns of myocardial fibrosis. J Mol Cell Cardiol. 1989; 21(Suppl 5): 121-131, indexed in Pubmed: 2534137.

12. Berk BC, Fujiwara K, Lehoux S. ECM remodeling in hypertensive heart disease. J Clin Invest. 2007; 117(3): 568-575, doi: 10.1172/ /JCl31044, indexed in Pubmed: 17332884.

13. López B, González A, Querejeta R, et al. Alterations in the pattern of collagen deposition may contribute to the deterioration of systolic function in hypertensive patients with heart failure. J Am Coll Cardiol. 2006; 48(1): 89-96, doi: 10.1016/j.jacc.2006.01.077, indexed in Pubmed: 16814653.

14. Kong $P$, Christia P, Frangogiannis NG. The pathogenesis of cardiac fibrosis. Cell Mol Life Sci. 2014; 71(4): 549-574, doi: 10.1007/s00018-013-1349-6, indexed in Pubmed: 23649149.

15. López B, González A, Díez J. Circulating biomarkers of collagen metabolism in cardiac diseases. Circulation. 2010; 121(14): 1645-1654, doi: 10.1161/CIRCULATIONAHA.109.912774, indexed in Pubmed: 20385961.

16. Dobaczewski M, Chen W, Frangogiannis NG. Transforming growth factor (TGF)- $\beta$ signaling in cardiac remodeling. J Mol Cell Cardiol. 
2011; 51(4): 600-606, doi: 10.1016/j.yjmcc.2010.10.033, indexed in Pubmed: 21059352.

17. Lipka D, Boratyński J. Metaloproteinazy MMP. Struktura i funkcja. Post Hig Med Dośw. 2008; 62: 328-336.

18. Sundström J, Evans JC, Benjamin EJ, et al. Relations of plasma matrix metalloproteinase-9 to clinical cardiovascular risk factors and echocardiographic left ventricular measures: the Framingham Heart Study. Circulation. 2004; 109(23): 2850-2856, doi: 10.1161/01. CIR.0000129318.79570.84, indexed in Pubmed: 15173025.

19. Martos R, Baugh J, Ledwidge M, et al. Diagnosis of heart failure with preserved ejection fraction: improved accuracy with the use of markers of collagen turnover. Eur J Heart Fail. 2009; 11(2): 191-197, doi: 10.1093/eurjhf/hfn036, indexed in Pubmed: 19168518.

20. Frantz S, Störk S, Michels K, et al. Tissue inhibitor of metalloproteinases levels in patients with chronic heart failure: an independent predictor of mortality. Eur J Heart Fail. 2008; 10(4): 388-395, doi: 10.1016/j.ejheart.2008.02.015, indexed in Pubmed: 18343723.

21. Zile MR, Desantis SM, Baicu CF, et al. Plasma biomarkers that reflect determinants of matrix composition identify the presence of left ventricular hypertrophy and diastolic heart failure. Circ Heart Fail. 2011; 4(3): 246-256, doi: 10.1161/CIRCHEARTFAILURE.110.958199, indexed in Pubmed: 21350055.

22. Zannad F, Alla F, Dousset B, et al. Limitation of excessive extracellular matrix turnover may contribute to survival benefit of spironolactone therapy in patients with congestive heart failure: insights from the randomized aldactone evaluation study (RALES). Rales Investigators. Circulation. 2000; 102(22): 2700-2706, indexed in Pubmed: 11094035.

23. Zannad F, Dousset B, Alla F. Treatment of congestive heart failure: interfering the aldosterone-cardiac extracellular matrix relationship. Hypertension. 2001; 38(5): 1227-1232, indexed in Pubmed: 11711528.

24. Cheng JM, Akkerhuis KM, Battes LC, et al. Biomarkers of heart failure with normal ejection fraction: a systematic review. Eur J Heart Fail. 2013; 15(12): 1350-1362, doi: 10.1093/eurjhf/hft106, indexed in Pubmed: 23845797.

25. López B, González A, Ravassa S, et al. Circulating biomarkers of myocardial fibrosis: the need for a reappraisal. J Am Coll Cardiol. 2015; 65(22): 2449-2456, doi: 10.1016/j.jacc.2015.04.026, indexed in Pubmed: 26046739.

26. López B, Querejeta Q, González A. Collagen cross-linking but not collagen amount associates with elevated filling pressures in hypertensive patients with stage $C$ heart failure: potential role of lysyl oxidase. Hypertension . 2012; 60(3): 677-683, doi: 10.1161/HYPERTENSIONAHA.112.196113, indexed in Pubmed: 22824984.

27. Zibadi S, Vazquez R, Moore D, et al. Myocardial lysyl oxidase regulation of cardiac remodeling in a murine model of diet-induced metabolic syndrome. Am J Physiol Heart Circ Physiol. 2009; 297(3): H976-H982, doi: 10.1152/ajpheart.00398.2009, indexed in Pubmed: 19592613.

28. López B, Querejeta R, González A, et al. Impact of treatment on myocardial lysyl oxidase expression and collagen cross-linking in patients with heart failure. Hypertension. 2009; 53(2): 236-242, doi: 10.1161/HYPERTENSIONAHA.108.125278, indexed in Pubmed: 19075089.

29. López B, Ravassa S, González A, et al. Myocardial collagen cross-linking is associated with heart failure hospitalization in patients with hypertensive heart failure. J Am Coll Cardiol. 2016; 67(3): 251-260, doi: 10.1016/j.jacc.2015.10.063, indexed in Pubmed: 26796388.
30. de Jong S, van Veen TAB, de Bakker JMT, et al. Biomarkers of myocardial fibrosis. J Cardiovasc Pharmacol. 2011; 57(5): 522-535, doi: 10.1097/FJC.0b013e31821823d9, indexed in Pubmed: 21423029.

31. Yang RY, Rabinovich GA, Liu FT. Galectins: structure, function and therapeutic potential. Expert Rev Mol Med. 2008; 10: e17, doi: 10.1017/ /S1462399408000719, indexed in Pubmed: 18549522.

32. Shah RV, Chen-Tournoux AA, Picard MH, et al. Galectin-3, cardiac structure and function, and long-term mortality in patients with acutely decompensated heart failure. Eur J Heart Fail. 2010; 12(8): 826-832, doi: 10.1093/eurjhf/hfq091, indexed in Pubmed: 20525986.

33. de Boer RA, Yu L, van Veldhuisen DJ. Galectin-3 in cardiac remodeling and heart failure. Curr Heart Fail Rep. 2010; 7(1): 1-8, doi: 10.1007/ /s11897-010-0004-x, indexed in Pubmed: 20425490.

34. Lok DJA, Van Der Meer P, de la Porte PWA, et al. Prognostic value of galectin-3, a novel marker of fibrosis, in patients with chronic heart failure: data from the DEAL-HF study. Clin Res Cardiol. 2010; 99(5): 323-328, doi: 10.1007/s00392-010-0125-y, indexed in Pubmed: 20130888.

35. de Boer RA, van Veldhuisen DJ, Gansevoort RT, et al. The fibrosis marker galectin-3 and outcome in the general population. J Intern Med. 2012; 272(1): 55-64, doi: 10.1111/j.1365-2796.2011.02476.x, indexed in Pubmed: 22026577.

36. Grandin EW, Jarolim P, Murphy SA, et al. Galectin-3 and the development of heart failure after acute coronary syndrome: pilot experience from PROVE IT-TIMI 22. Clin Chem. 2012; 58(1): 267-273, doi: 10.1373/clinchem.2011.174359, indexed in Pubmed: 22110019.

37. de Boer RA, Lok DJA, Jaarsma T, et al. Predictive value of plasma galectin-3 levels in heart failure with reduced and preserved ejection fraction. Ann Med. 2011; 43(1): 60-68, doi: 10.3109/07853890.20 10.538080, indexed in Pubmed: 21189092.

38. Lin YH, Lin LY, Wu YW, et al. The relationship between serum galectin-3 and serum markers of cardiac extracellular matrix turnover in heart failure patients. Clin Chim Acta. 2009; 409(1-2): 96-99, doi: 10.1016/j.cca.2009.09.001, indexed in Pubmed: 19747906.

39. Gullestad L, Ueland T, Kjekshus J, et al. CORONA Study Group. Galectin-3 predicts response to statin therapy in the Controlled Rosuvastatin Multinational Trial in Heart Failure (CORONA). Eur Heart J. 2012; 33(18): 2290-2296, doi: 10.1093/eurheartj/ehs077, indexed in Pubmed: 22513778.

40. Zamora E, Lupón J, de Antonio M, et al. Renal function largely influences Galectin-3 prognostic value in heart failure. Int J Cardiol. 2014; 177(1): 171-177, doi: 10.1016/j.ijcard.2014.09.011, indexed in Pubmed: 25499371.

41. AbouEzzeddine OF, Haines P, Stevens S, et al. Galectin-3 in heart failure with preserved ejection fraction. A RELAX trial substudy (Phosphodiesterase-5 Inhibition to Improve Clinical Status and Exercise Capacity in Diastolic Heart Failure). JACC Heart Fail. 2015; 3(3): 245-252, doi: 10.1016/j.jchf.2014.10.009, indexed in Pubmed: 25742762.

42. Carthew RW, Sontheimer EJ. Origins and mechanisms of miRNAs and siRNAs. Cell. 2009; 136(4): 642-655, doi: 10.1016/j.cell. 2009.01.035, indexed in Pubmed: 19239886.

43. Weber JA, Baxter DH, Zhang S, et al. The microRNA spectrum in 12 body fluids. Clin Chem. 2010; 56(11): 1733-1741, doi: 10.1373/ /clinchem.2010.147405, indexed in Pubmed: 20847327.

44. Tijsen AJ, Pinto YM, Creemers EE. Non-cardiomyocyte microRNAs in heart failure. Cardiovasc Res. 2012; 93(4): 573-582, doi: 10.1093/ /cvr/cvr344, indexed in Pubmed: 22180601. 
45. Thum T. Noncoding RNAs and myocardial fibrosis. Nat Rev Cardiol. 2014; 11(11): 655-663, doi: 10.1038/nrcardio.2014.125, indexed in Pubmed: 25200283.

46. Roy S, Khanna S, Hussain SRA, et al. MicroRNA expression in response to murine myocardial infarction: miR-21 regulates fibroblast metalloprotease-2 via phosphatase and tensin homologue. Cardiovasc Res. 2009; 82(1): 21-29, doi: 10.1093/cvr/cvp015, indexed in Pubmed: 19147652.

47. Liang $\mathrm{H}$, Zhang $\mathrm{C}$, Ban $\mathrm{T}$, et al. A novel reciprocal loop between microRNA-21 and TGFBRIII is involved in cardiac fibrosis. Int J Biochem Cell Biol. 2012; 44(12): 2152-2160, doi: 10.1016/j.biocel.2012.08.019, indexed in Pubmed: 22960625.

48. Villar AV, García R, Merino D, et al. Myocardial and circulating levels of microRNA-21 reflect left ventricular fibrosis in aortic stenosis patients. Int J Cardiol. 2013; 167(6): 2875-2881, doi: 10.1016/j. ijcard.2012.07.021, indexed in Pubmed: 22882958.

49. van Rooij E, Sutherland LB, Thatcher JE, et al. Dysregulation of microRNAs after myocardial infarction reveals a role of miR-29 in cardiac fibrosis. Proc Natl Acad Sci U S A. 2008; 105(35): 13027-13032, doi: 10.1073/pnas.0805038105, indexed in Pubmed: 18723672.

50. Roncarati R, Viviani Anselmi C, Losi MA, et al. Circulating miR-29a, among other up-regulated microRNAs, is the only biomarker for both hypertrophy and fibrosis in patients with hypertrophic cardiomyopathy. J Am Coll Cardiol. 2014; 63(9): 920-927, doi: 10.1016/j. jacc.2013.09.041, indexed in Pubmed: 24161319.

51. Goren $\mathrm{Y}$, Kushnir M, Zafrir B, et al. Serum levels of microRNAs in patients with heart failure. Eur J Heart Fail. 2012; 14(2): 147-154, doi: 10.1093/eurjhf/hfr155, indexed in Pubmed: 22120965. 